\title{
Towards understanding Cameraria ohridella (Lepidoptera: Gracillariidae) development: effects of microhabitat variability in naturally growing horse-chestnut tree canopy
}

\author{
Piotr Łaszczyca ${ }^{1}$ - Mirosław Nakonieczny ${ }^{1}$ (1) $\cdot$ Andrzej Kędziorski ${ }^{1} \cdot$ Agnieszka Babczyńska $^{1} \cdot$ Marta Wiesner $^{1,2}$
}

Received: 23 July 2020 / Revised: 9 March 2021 / Accepted: 22 March 2021 / Published online: 21 April 2021

(C) The Author(s) 2021

\begin{abstract}
Dwelling intensity of horse-chestnut miner (Cameraria ohridella) larvae in various leaves insolation and temperature was measured to determine whether this pest's development follows a predictable pattern or depends more on local microenvironment conditions. Mines growing on leaves of mature host plants (Aesculus hippocastanum L.) in their natural conditions were photographed for two consecutive generations of the pest and in two separated vegetation periods. Apart from meteorological data obtained from the nearest station, the temperature of intact and mined parts of sun-exposed and shaded leaf blades was measured at various daytimes throughout the experiment. Obtained sets of digital data were analysed and combined to model mine area growth as a function of degree-days sum by adopting of Verhulst logistic equation. We showed the predictive potential of our model based on experimental data, and it may be useful in the scheduling of pest control measures in natural conditions. Our analyses also revealed that despite significant differences in microenvironment conditions depending on mines' insolation, the horse-chestnut miner larvae could partially compensate for them and complete their development at similar endpoints expressed as the cumulative sum of degree-days. We conclude that computer-aided analysis of photographic documentation of leaf-miner larval growth followed by mathematical modelling offers a noninvasive, reliable, and inexpensive alternative for monitoring local leaf-miners populations.
\end{abstract}

Keywords Degree-days $\cdot$ Horse-chestnut leaf-miner $\cdot$ Image analysis $\cdot$ Microhabitat $\cdot$ Mine size $\cdot$ Model of development

\section{Introduction}

The progressive invasion of horse-chestnut leaf-miner Cameraria ohridella Deschka and Dimic 1986 (Lepidoptera, Gracillariidae) in Europe since 1990s has stimulated much research on the pest's biology, impact, and management (Tomiczek and Krehan 1998; Akimov et al. 2003; Gilbert

Mirosław Nakonieczny

miroslaw.nakonieczny@us.edu.pl

1 Faculty of Natural Sciences, Institute of Biology, Biotechnology and Environmental Protection, Animal Physiology and Ecotoxicology Team, University of Silesia in Katowice, PL 40-007 Katowice, Bankowa 9, Poland

2 Główny Instytut Górnictwa (GIG), 40-166 Katowice, plac Gwarków 1 , Poland et al. 2005; Kenis et al. 2005; Girardoz et al. 2007; Syeryebryennikov et al. 2008; Stygar et al. 2013; Pocock and Evans 2014). Across its present range that spans from Greece and Balkan countries (C. cameraria refugium until the end of the 1980s) to Scandinavia and England (invaded in 2000-2005), the pest has 2-4 partially overlapping generations during the vegetation period (Dimic et al. 2000; Buszko 2006; Pocock and Evans 2014). The rate of larval development and moulting results from the sum of effective temperatures above the lower threshold that is usually described as the sum of degree-days or growth degree-days (Dimic et al. 2000; Dautbašić 2006; Meshkova and Mikulina 2013). Recent molecular studies revealed small genetic variability among invasive populations compared with native horsechestnut leaf-miner populations inhabiting the Balkans, considered the most likely area of the pest's origin in Europe (Valade et al. 2009; Lees et al. 2011). Thus, any differences in the pest development on invaded areas can be merely ascribed to local variability of biotope conditions. 
Although calculations of growth degree-days have been common practice for numerous pest species, predictions of leaf-miners development based on air temperature might be less accurate due to variation of local thermal conditions among particular mines depending on their exposure to sunlight (Pincebourde and Casas 2006a, b; Pincebourde and Woods 2012). 'Thermal variation' within local microenvironment affects performance (e.g. rate of development or activity) in numerous ectotherms, and leaf-dwellers are no exception here (Angilletta Jr. et al. 2002; Niehaus et al. 2012; Pincebourde and Woods 2012). Moreover, sun-exposed leaves have thicker mesophyll layers, hence greater biomass per unit area, than leaves growing in the shade; furthermore, they contain more secondary metabolites (Adams and Langton 2005; Fritz et al. 2018; Yang et al. 2018).

Larval development of $C$. ohridella depends on light conditions and position within the tree canopy (Birner and Bohlander 2004; Horváth and Benedek 2009). Recently, Jagiełło et al. (2019) in a glasshouse experiment demonstrated more extensive mine area in low light than in high light but the same mass eaten by the larvae due to the thicker leaf blade in high light conditions. However, a glasshouse experiment cannot mimic the complexity of microenvironment conditions that affect leaf-dwellers in their natural habitat. Moreover, it has been shown that senescence of autumn leaves increased C. ohridella larvae mortality (Samek 2003; Girardoz et al. 2007). Thus, the question remains whether the completion of larval development in sun-exposed vs shaded leaves depends more on the leaf 'quality' or amount of heat (sum of effective temperatures in microenvironment of particular larvae) in their natural conditions and whether it follows a predictable pattern.

We combined quantitative data of individual larvae mining of two consecutive generations with meteorological data to create a mathematical model of $C$. ohridella development in the growing season. Then we critically tested the model's accuracy in predicting the pest phenology and its utility for timing control measures, e.g. applying pheromonal traps for moths.

\section{Material and methods}

\section{Experimental setup and data collection of mine- dwelling activity}

Observations were carried out in 2009 (5th May-23rd August) and 2013 (6th June-13th September) on mines of C. ohridella on Aesculus hippocastanum L. specimens, about 20 years old, growing in a large urban park $\left(50.2912^{\circ} \mathrm{N}\right.$, $18.9774^{\circ} \mathrm{E}$, Chorzów, Poland). Randomly selected young leaves, accessible from the ground, with different numbers of mines (in an initial stadium), were tape-marked on their petioles, numbered and classified into two groups, depending on their position within the canopy: sun-exposed (Sun) located on southern and superficial part of the canopy and not obscured by other leaves and shaded (Shade) — on the northern part of the foliage and void of direct sun rays. Other trees did not shade the selected $A$. hippocastanum canopies.

In 2009, we photographed 14 Sun and 8 Shade leaves 13 times each during the first generation (final moult on 23rd July) and 8 Sun and 8 Shade leaves 9 times during the second generation. Only partial examination of the second generation was possible due to accidental damage of our test foliage by the park service. We documented mine development with 1402 and 716 photographs of the leaves for the first and second generations (see below). In 2013, we photographed 10 Sun and 9 Shade leaves 8 times each during the first generation (6th June-17th July) and 9 Sun and 9 Shade leaves 8 times each during the second generation (26th July-28th August), so the mine's development was documented with 1540 photographs altogether (Fig. 1). The caterpillars of all inspected mines pupated and finally emerged as mature moths. Thus we concluded that the larvae were not parasitised.

Additionally, mean fresh and dry mass per surface area was calculated for randomly selected 8-9 leaflets for each lighting condition at a particular date, with 52 samples altogether.

\section{Data elaboration and model construction}

Images of mined leaves were captured with Olympus FE20 camera (min. resolution $4600 \times 3450$ px, c.a. $4 \mathrm{MB}$ per image) against a graph paper. Images were adjusted with ImageJ 1.41 software (http://imagej.nih.gov/ij/) and GIMP or CorelDraw ${ }^{\circledR}$ to correct the accidental distortion of the leaf plane. The adjustment included image scaling and filtering with built-in Object-Based Image Analysis modules of ImageJ® (for better contrast between mined and intact parts of the leaf and setting threshold values of the measured areas), followed by 'automatic' area measurements (in $\mathrm{mm}^{2}$ ). Data transformation to relative values eliminated problems with image distortion and calibration. The mines were measured either on randomly selected leaflet(s) of the leaf (in 2009) or all leaflets of the chosen leaves (in 2013).

The Image J® data for each experimental group (including the year of study, the pest generation, and the leaf 'group') were elaborated statistically for comparison and developmental model construction. Relative mine surface area $(\mathrm{rA})$ in the period of generation growth was calculated, taking the maximum value of average mine surface for that generation as the basis for estimation. In the next step, rA (Sun/Shade) was plotted as a function of time (days) or sum of degree-days (see below). Verhulst logistic equation was subsequently applied to the data, and parameters of the equation were calculated with the 


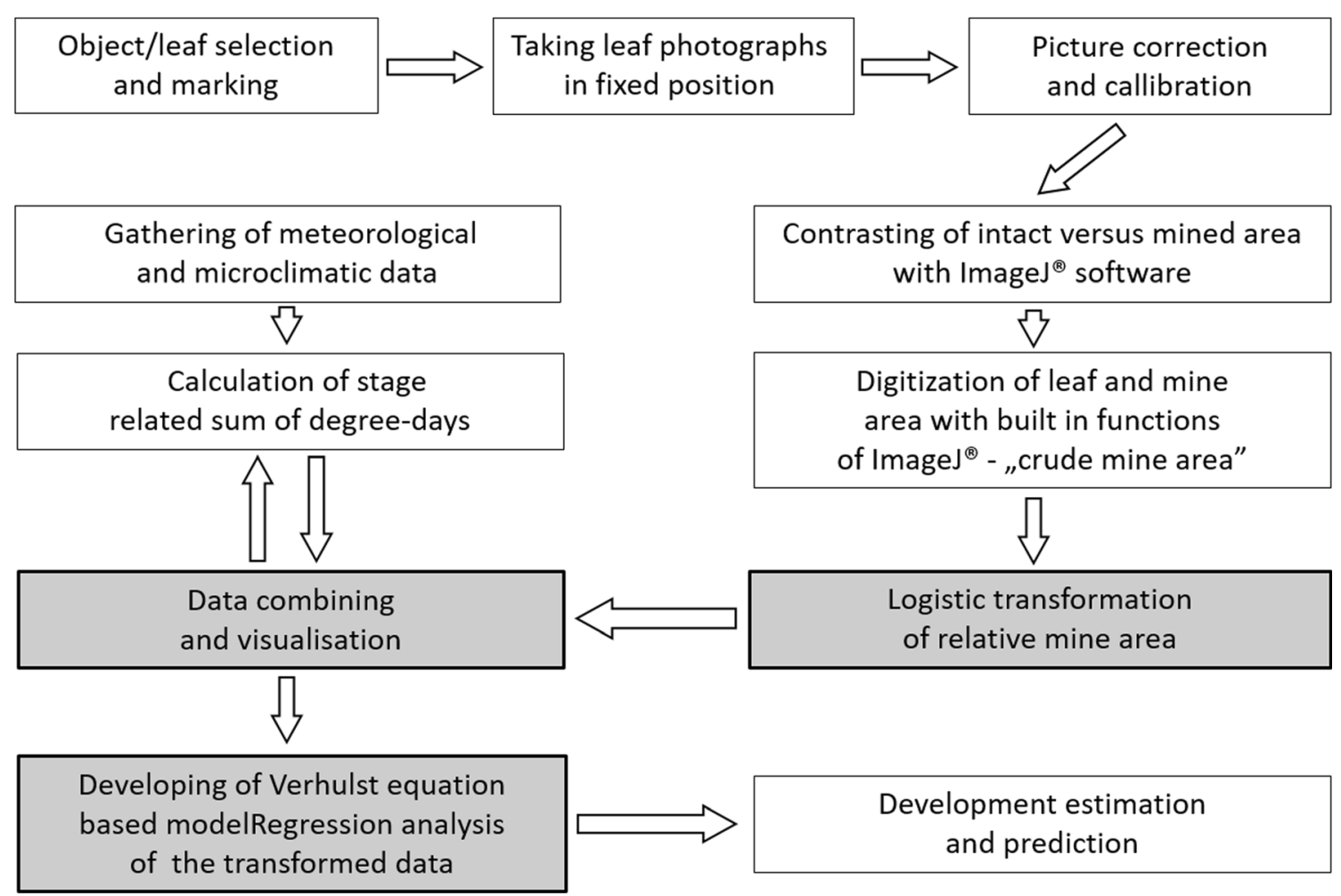

Fig. 1 Subsequent steps of degree-day based model elaboration of leaf-miner Cameraria ohridella (Lepidoptera, Gracillariidae) infestation on host leaves

appropriate regression model. The final linear regression model was built using MS Excel® formulas, based on Verhulst logistic equation (Eqs. (1) and (2)) after logit data transformation of average mine surfaces (Tsoularis 2001; Tsoularis and Wallace 2002; Vandermeer 2010):

$$
\begin{aligned}
& \frac{d N}{d t}=r N \cdot \frac{K-N}{K} \\
& N_{t}=\frac{K}{1+e^{a-r t}}
\end{aligned}
$$

where $N$ is the variable describing temporary population growth (here = mine area), $K$ is the corresponding maximal value (here $=$ maximal mine area measured for given generation), $r$ is the rate of growth/coefficient/, $t$ is the independent variable (here $=$ time or sum of effective temperatures), $a$ is the constant of integration (from regression equation), and $e$ is the base of natural logarithm.

Logit linear transformation was based on the following formulas (Eqs. (3) and (4)) (McDonald 2014):

$$
\begin{aligned}
\operatorname{Logit}\left(N_{t}\right) & =\frac{\ln N_{t}}{1-N_{t}} \\
\operatorname{Logit}\left(N_{t}\right) & =r \cdot t-a
\end{aligned}
$$

Parameters of the linear equation (slope, intercept, correlation coefficient, and error of estimation) were obtained by LSD methods and MS Excel® formulas.

\section{Collection of microclimatic data}

The Central Mining Institute's meteorological station in Katowice $\left(50.2709^{\circ} \mathrm{N}, 19.0259^{\circ} \mathrm{E}\right.$ - about $6 \mathrm{~km}$ away from the experimental stand) provided data including minimum and maximum daily temperature and air humidity, throughout the whole observation periods in 2009 and 2013.

Temperature data were used to calculate the sum of effective temperatures (day-degree sum). We chose $0{ }^{\circ} \mathrm{C}$ as the basis for calculations instead of about $8-10{ }^{\circ} \mathrm{C}$ assumed by some authors as low developmental threshold for $C$. ohridella and other Lepidoptera (Doganlar 2008; Nietschke et al. 2007; Meshkova and Mikulina 2013; Jarošík et al. 2015). Such an approach avoids the possible error of overestimating the actual developmental threshold that may be lower in the leaf-miner populations invading Europe in northward direction (see 'Discussion').

Estimated surfaces of the photographed mines were plotted against time from the onset of observations, or sum of effective temperatures.

Microclimatic data were obtained for the leaves of horsechestnut trees growing in the experimental stand, Katowice Forest Park $\left(50.2331^{\circ} \mathrm{N}, 19.0204^{\circ} \mathrm{E}\right)$, Kosciuszko Park $\left(50.239881^{\circ} \mathrm{N}, 19.003296^{\circ} \mathrm{E}\right)$, and in the small town garden $\left(50.2590^{\circ} \mathrm{N}, 19.0287^{\circ} \mathrm{E}\right)$. The canopy's air temperature was measured about $2-5 \mathrm{~cm}$ over the leaf surface with a noncontact digital infrared sensor with $\pm 0.3{ }^{\circ} \mathrm{C}$ accuracies (model 
ST8806H, Standard Instruments Co., Ltd). The leaf surface temperature was recorded by the same means at intact and damaged parts of sun-exposed and shaded leaves at different times of the day and insolation conditions. Relative air humidity within the canopy was measured with Infrared Psychrometer AZ 8857 (AZ Instruments, Taiwan) 5-10 cm away from the examined leaf blade.

Fresh and dry mass (per unit of leaf area) of intact parts of infested leaflets was also determined for crude assessment of biomass consumption by larvae.

\section{Results}

Traces of leaf-mining by the first-generation larvae appeared in the middle of May 2009 but in early June 2013 (probably due to cold April). Final moulting of the first generation was observed 16-20th of July and early mines of the nextgeneration larvae at the end of July in both 2009 and 2013. The mines were growing until 13th September 2013 (some of the observed leaves had fallen a week earlier) occupying up to about $25 \%$ of the total leaf area (quartile range: $15-31 \%$ ).

Two independent developmental datasets - measurements of mines on particular leaflets (in 2009) and total mined area of selected leaves (in 2013 - allowed construction of a reliable mathematical model of $C$. ohridella development on horsechestnut leaves. The mean mine area's growth with time followed a double S-shaped curve with 'plateau phase' between consecutive generations, which corresponded to pupal stage and adult emergence (Table 1, relative values; Fig. 2, absolute values). Larger area mines occurred on shaded than on the sun-exposed leaves (Fig. 2; Tables 1 and 2).

The observed 'plateau' on the curve provided a reference value for calculating relative mine growth (from the raw data) for the first generation. This step made the results independent of a random selection of the leaflets and suitable for constructing the mathematical model of development (see Fig. 3 as an example of such transformation).

\section{Modelling of Cameraria ohridella development on horse-chestnut leaves}

The standardised data for each generation of $C$. ohridella larvae were used to find the Verhulst logistic equation best fitted to the experimental data. Logit transformation followed by regression analysis yielded the parameters of the Verhulst equation. They were similar for both the leaflets and the whole leaves datasets (Tables 3 and 4; Figs. 2 and 3). We used these parameters to fill the missing developmental data of the second-generation larvae in 2009. The set data were 774.5 and 901.3 degree-days for development of the mine to $\mathrm{rA}=$ 0.995 for sun-exposed and shaded leaves, respectively. Estimated range of degree-days sum for these calculated values was 751-835 (2009-09-01) in sunny and 837-964 (2009-09-08) in shaded conditions. Such estimation accuracy corresponds to about $4-5$ days of larval development (Table 1).

\section{Effect of leaves exposure to sunlight on the dynamics of mine dwelling}

During both generations observed in 2013, shaded leaves appeared more severely damaged than sun-exposed ones, but the Kruskal-Wallis test showed no significant difference (Table 2). Estimated time and number of degree-days necessary for the emergence of $C$. ohridella larvae suggested longer development of the second (summer) generation than the first (spring) one (Table 1, Fig. 2). However, regression values did not reveal significant effects of possible causal factorsneither the time of development nor the sum of degree-days (Tables 3 and 4). These results suggest that more data are necessary to resolve whether the inter-generation difference exists.

Fresh and dry mass (per area unit) of the leaf blade was higher for sun-exposed leaves than for shaded ones, suggesting their higher calorific and/or nutritional value. This difference increased with the leaf senescence (Table 5).

\section{Leaf and mine microclimate}

The temperature of sun-exposed leaves was higher than air temperature already in the morning $\left(3{ }^{\circ} \mathrm{C}\right.$ at $\left.7 \mathrm{AM}\right)$ and exceeded $6{ }^{\circ} \mathrm{C}$ about noon and early afternoon (3 PM). On the contrary, the temperature of shaded leaves was $1{ }^{\circ} \mathrm{C}$ lower than the morning's air temperature and as much as $4{ }^{\circ} \mathrm{C}$ lower by midday. Hence, the difference between sun-exposed and shaded leaves exceeded $11{ }^{\circ} \mathrm{C}$ during the midday and was higher than changes in air temperature (Table 6).

Sun rays falling on the intact leaf surface raised its temperature by $5-6{ }^{\circ} \mathrm{C}$ within a minute. Damaged leaf area had even greater temperature fluctuations in response to sunlight. Statistical analysis (ANCOVA) revealed a significant effect of mine 'type' (white or brown) and insolation on the mine temperature. The surface temperature of new mines was like an intact blade but $2.8 \pm 1.7^{\circ} \mathrm{C}$ higher in brown, empty mines exposed to sunlight $(p=0.009)$. Mines on shaded leaflets had $0.2 \pm 0.1{ }^{\circ} \mathrm{C}$ lower surface temperature than undamaged areas (Fig. 4).

Relative humidity within the horse-chestnut canopy ranged from 43 to $69 \%$ (lower and upper quartile) and was higher during morning and evening hours and lowered at noon and early afternoon.

These results suggest another unknown factor responsible for a similar rate of the larvae development on shaded and sunexposed leaves (see 'Discussion'). 
Table 1 Relative mean area of Cameraria. ohridella mines (rA) on sun-exposed and shaded leaves of Aesculus hippocastanum and the corresponding sum of degree-days during the development of two consecutive generations of the pest in 2013 (changes of the whole mined area of the leaf) and 2009 (changes of selected mines area on particular leaves)

\begin{tabular}{|c|c|c|c|c|c|c|c|}
\hline \multirow[t]{3}{*}{ Date } & & \multirow[t]{3}{*}{ Day } & \multirow[t]{3}{*}{$\sum$ degree-days } & \multicolumn{4}{|c|}{ Relative values of mine size/area on leaves (rA) } \\
\hline & & & & \multicolumn{2}{|c|}{ Sun exposed } & \multicolumn{2}{|l|}{ Shaded } \\
\hline & & & & Mean & $\mathrm{SD}$ & Mean & SD \\
\hline \multicolumn{8}{|l|}{2013} \\
\hline 2013-06-06 & I generation & 1 & 15.6 & 0.003 & 0.006 & 0.021 & 0.024 \\
\hline 2013-06-13 & & 8 & 163.9 & 0.019 & 0.014 & 0.034 & 0.035 \\
\hline 2013-06-20 & & 15 & 337.6 & 0.067 & 0.046 & 0.097 & 0.117 \\
\hline 2013-06-27 & & 22 & 482.7 & 0.257 & 0.193 & 0.239 & 0.166 \\
\hline 2013-07-02 & & 27 & 578.7 & 0.466 & 0.520 & 0.306 & 0.206 \\
\hline 2013-07-11 & & 36 & 790.7 & 0.872 & 0.714 & 0.927 & 0.718 \\
\hline 2013-07-17 & & 42 & 909.7 & 1.000 & 0.835 & 1.000 & 0.735 \\
\hline 2013-07-26 & II generation & 1 & 25.9 & 0.049 & 0.044 & 0.053 & 0.060 \\
\hline 2013-08-01 & & 7 & 200.8 & 0.107 & 0.063 & 0.100 & 0.079 \\
\hline 2013-08-11 & & 17 & 486.0 & 0.472 & 0.218 & 0.197 & 0.105 \\
\hline 2013-08-14 & & 20 & 547.0 & 0.644 & 0.272 & 0.480 & 0.306 \\
\hline 2013-08-19 & & 25 & 662.1 & 0.786 & 0.267 & 0.717 & 0.533 \\
\hline 2013-08-28 & & 34 & 827.6 & 0.988 & 0.299 & 0.864 & 0.509 \\
\hline 2013-09-13 & & 50 & 1108.4 & 1.000 & 0.290 & 1.000 & 0.523 \\
\hline \multicolumn{8}{|l|}{2009} \\
\hline 2009-05-20 & I generation & 1 & 16.0 & 0.001 & 0.000 & 0.000 & 0.000 \\
\hline 2009-06-01 & & 13 & 183.5 & 0.003 & 0.003 & 0.003 & 0.002 \\
\hline 2009-06-06 & & 18 & 239.1 & 0.009 & 0.006 & 0.008 & 0.005 \\
\hline 2009-06-10 & & 22 & 308.5 & 0.019 & 0.014 & 0.023 & 0.011 \\
\hline 2009-06-16 & & 28 & 399.8 & 0.035 & 0.026 & 0.044 & 0.021 \\
\hline 2009-06-20 & & 32 & 462.8 & 0.066 & 0.058 & 0.092 & 0.044 \\
\hline 2009-06-30 & & 42 & 635.9 & 0.178 & 0.098 & 0.217 & 0.081 \\
\hline 2009-07-04 & & 46 & 720.6 & 0.306 & 0.141 & 0.353 & 0.117 \\
\hline 2009-07-07 & & 49 & 780.9 & 0.454 & 0.204 & 0.499 & 0.156 \\
\hline 2009-07-11 & & 53 & 842.5 & 0.615 & 0.279 & 0.650 & 0.199 \\
\hline 2009-07-14 & & 56 & 898.8 & 0.794 & 0.370 & 0.813 & 0.259 \\
\hline 2009-07-23 & & 65 & 1089.1 & 1.000 & 0.474 & 1.000 & 0.372 \\
\hline 2009-07-30 & II generation & 1 & 21.0 & 0.001 & 0.001 & 0.000 & 0.000 \\
\hline 2009-08-02 & & 4 & 83.6 & 0.005 & 0.005 & 0.001 & 0.001 \\
\hline 2009-08-05 & & 7 & 141.3 & 0.012 & 0.012 & 0.004 & 0.001 \\
\hline 2009-08-07 & & 9 & 180.2 & 0.027 & 0.024 & 0.009 & 0.004 \\
\hline 2009-08-14 & & 16 & 300.8 & 0.077 & 0.051 & 0.029 & 0.012 \\
\hline 2009-08-19 & & 21 & 398.8 & 0.138 & 0.079 & 0.062 & 0.028 \\
\hline 2009-08-23 & & 25 & 475.0 & 0.211 & 0.103 & 0.101 & 0.041 \\
\hline 2009-08-28 & & 30 & 708.2 & $\ldots$ & $\ldots$ & $\ldots$ & $\ldots$ \\
\hline 2009-09- 01 & & 34 & 775.2 & $* 0.995$ & & & \\
\hline 2009-09-05 & & 38 & 839.8 & $\ldots$ & $\ldots$ & $\ldots$ & $\ldots$ \\
\hline 2009-09-08 & & 41 & 889.5 & & & $* 0.995$ & \\
\hline 2009-09-11 & & 44 & 946.2 & $\ldots$ & $\ldots$ & $\ldots$ & $\ldots$ \\
\hline
\end{tabular}

Relative mine surface area (rA) during the given generation's growth was calculated against maximal value of average mine surface for the given generation. In 2009, final values of mine size $(r A=0.995)$ for the second generation (marked by *) were estimated from Verhulst formula (see text for explanation) 

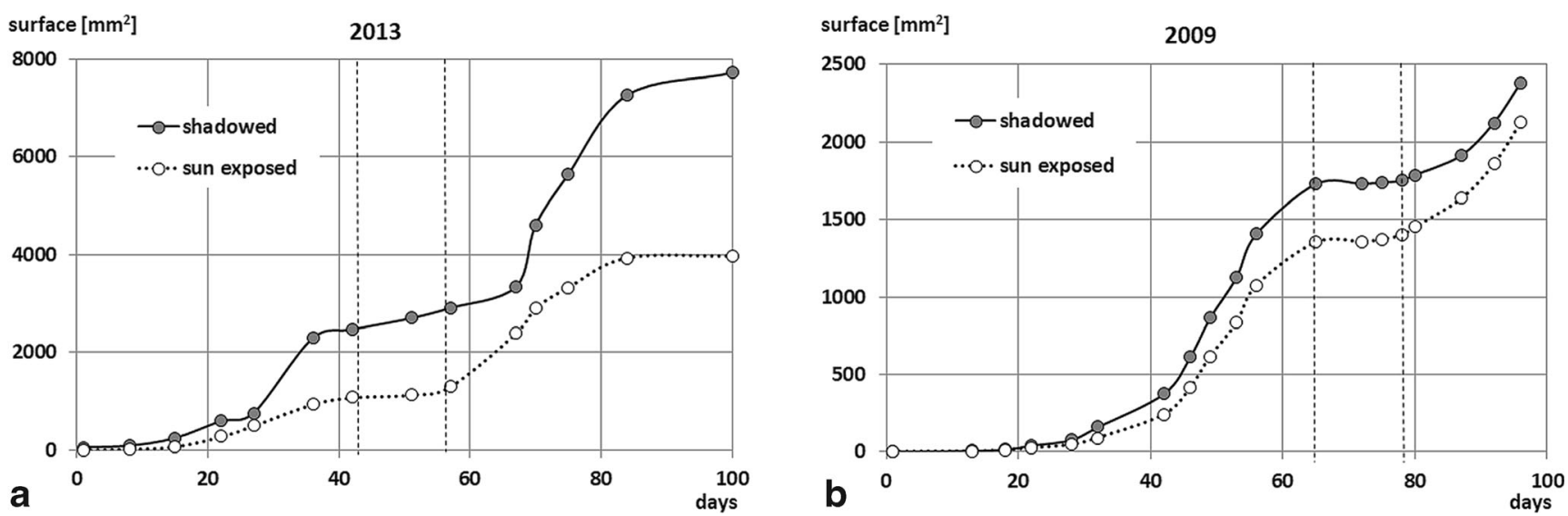

Fig. 2 Total mine surface increase on the sun-exposed and shaded leaves of Aesculus hippocastanum during the development of two consecutive generations of Cameraria ohridella in 2013 (a sum of mines area per leaf) and 2009 (b mine area of selected mines on the leaf)

\section{Discussion}

Moths of C. ohridella in Balkans emerge at the end of March, and caterpillars of the last, third-generation finish their feeding by mid-November. Pupal and adult stages overlap by 10 to 30 days, while moths and next-generation larvae overlap by 10 20 days. Although 40 days is sufficient for individual larvae to reach pupal stage, the first, second, and third generations need 50,60 , and 90 days, respectively, to complete larval development (Dimic et al. 2000; Samek 2003; Girardoz et al. 2007; D'Costa et al. 2013).

The Ukrainian population of $C$. ohridella (green stands in Kharkiv) also has three generations, and their development depends on the prevailing temperature conditions. Completion of larval stage required on average 22.8, 16.8, and 34.6 days for subsequent generations that corresponded to 203.5, 193.8, and 262.3 degree-days (effective temperatures calculated over $10{ }^{\circ} \mathrm{C}$ threshold value), respectively (Meshkova and Mikulina 2013). The detailed study performed by the authors in five consecutive years (2008-2012) revealed that larval developmental time correlated better with the sum of corresponding positive temperatures than the sum of effective temperatures $(r=0.882$ vs $r=0.777$ and $r=0.944$ vs $r=0.921$ for larvae of the first and second generation, respectively). Moreover, duration of the third-generation larvae did not correlate with positive temperatures but negatively correlated ( $r=-0.891)$ with effective temperatures instead, during the analysed period, suggesting an involvement of other environmental factors shaping the pest's development. These results support our assumption of $0{ }^{\circ} \mathrm{C}$ as a basis for calculations of $C$. ohridella thermal requirements.

Häffner and Schroer (2011) suggested that the horsechestnut leaf-miner may develop faster under warmer and artificially illuminated microclimate yielding three to four generations in Berlin and up to five in warmer regions. However, completion of development by subsequent generations may also depend on nutritional value and defensive allomones content of the leaves. Shaded leaves within the canopy contain lower amounts of these secondary metabolites (Yang et al. 2018; Jagiełło et al. 2019). Moreover, larger size mines made by the second-generation larvae, irrespective of the light conditions, suggest deterioration of nutritional quality with leaf age (Table 1; Figs. 2 and 3) (Samek 2003; Girardoz et al. 2007).

The concept of sum of effective temperatures (or similar indices like growing degree-days) as a predictor of development rate of organisms in the ambient environment was criticised due to large circadian variability of thermal
Table 2 Percentage of total leaf surface mined in Aesculus hippocastanum leaves during the experiment

\begin{tabular}{|c|c|c|c|c|c|c|c|c|}
\hline & \multicolumn{4}{|c|}{$\%$ of leaf surface mined in 2013} & \multicolumn{4}{|c|}{$\%$ of leaf surface mined in 2009} \\
\hline & \multicolumn{2}{|c|}{ At the first day } & \multicolumn{2}{|c|}{ At the last day } & \multicolumn{2}{|c|}{ At the first day } & \multicolumn{2}{|c|}{ At the final day $(*)$} \\
\hline & Sun & Shadow & Sun & Shadow & Sun & Shadow & Sun & Shadow \\
\hline Median & 0.006 & 0.084 & 18.5 & 26.5 & 0.075 & 0.110 & 13.5 & 12.0 \\
\hline Q25 & 0.004 & 0.061 & 15.6 & 22.4 & 0.065 & 0.085 & 10.4 & 11.1 \\
\hline Q75 & 0.007 & 0.165 & 22.6 & 30.7 & 0.335 & 0.170 & 16.8 & 15.8 \\
\hline
\end{tabular}

The values 'on the last day' (of observation) represent the sum of damage areas caused by two generations larvae; (*) observations ceased due to accidental damage of the tested foliage; Q25 and Q75, the first and third quartiles 


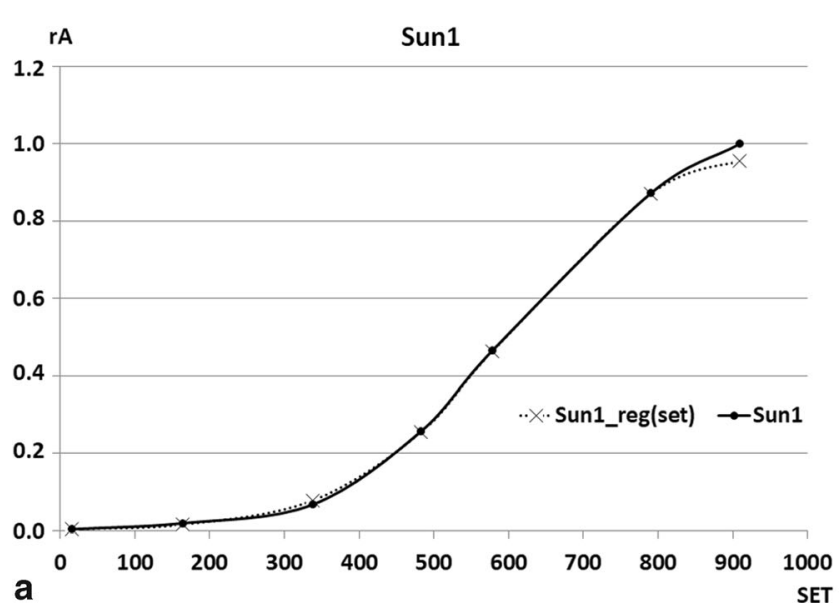

Fig. 3 Steps of the computation procedure applied to the mine size of the first generation of Cameraria ohridella on sun-exposed leaves in 2013. a Mean relative mine area $[\mathrm{rA}]$ plotted against sum of effective temperatures $[\mathrm{SET}]$ in degree-days, Sun1 (solid line) - rA obtained from measurements, Sun1_reg(set) (dashed line) - rA computed from logit-based

conditions and insolation (Solantie 2004). Nevertheless, many authors used this concept for numerous species, particularly important in agriculture (Hanula et al. 1987; Zou et al. 2004; Bergant and Trdan 2006; Doganlar 2008; Murray 2008; Dixon et al. 2009; Jarosík et al. 2011). Complex interactions among ambient thermal conditions and developmental rate in insects within the range of natural environmental temperature variability $\left(10-35^{\circ} \mathrm{C}\right)$ can be simplified by the linear daydegree sum model ('law of total effective temperatures') (Damos and Savopoulou-Soultani 2012) or mean daily temperature (Nielsen et al. 2016). In the presented work, sum of degree-days was estimated according to almost 'historical method' - calculation of the mean daily temperature from eight measurements taken every $3 \mathrm{~h}$ at the nearest weather

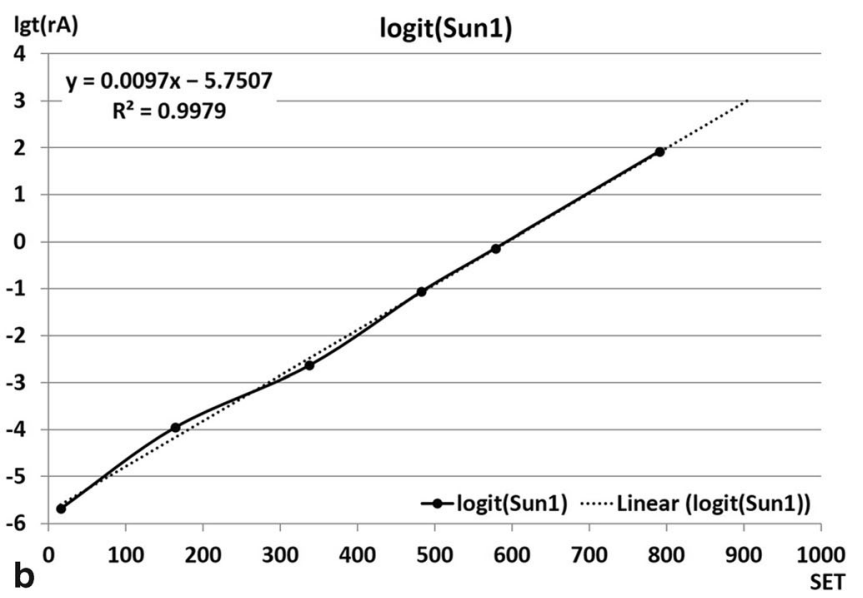

linear regression; b Logit-transformed mean relative mine area $[\operatorname{lgt}(\mathrm{rA})]$ plotted against sum of effective temperatures [set] in degree-days, logit(Sun1) (solid line) - rA experimental data after logit transformation, linear_reg(set) (dashed line) - logit-based linear regression curve optimised with LSD method

station (Pruess 1983; Felber et al. 2018). Despite some disadvantage (lack of local radiation and microclimate variability data on experimental stands), the method gives a good approximation of conditions determining the development of minedwelling larvae, confirmed by high values of correlation coefficients for presented equations. Hence, our developed model should confirm its predictive potential also when applied to seminatural conditions like greenhouse experiments (see Jagiełło et al. 2019).

Some studies suggest that leaf-miners and leaf-gallers prefer sun-exposed leaves over those growing in the shade (Dai et al. 2013; Alexandre et al. 2018), but Horváth and Benedek (2009) pointed out that the preference of $C$. ohridella for shaded vs sun-exposed leaves likely results from seasonal
Table 3 Parameters of linearised Verhulst equation (Eq. (4)) based on the logistic model of mine area increase dynamics in two generations (1 and 2) of Cameraria ohridella larvae dwelling in isolated (Sun) and shaded (Shade) leaves in 2013 and 2009

\begin{tabular}{|c|c|c|c|c|c|c|c|c|}
\hline \multirow[t]{2}{*}{ Group } & \multicolumn{2}{|l|}{ Days } & \multicolumn{6}{|c|}{ Degree-days ('set') } \\
\hline & $r$ & $a$ & $r$ & $a$ & $R$ & $E$ & SE & $n$ \\
\hline 2013_Sun1 & 0.214 & 5.81 & 0.00969 & 5.751 & 0.999 & 0.0772 & 0.00022 & 6 \\
\hline $\begin{array}{l}2013 \text { Shade1 } \\
\text { She }\end{array}$ & 0.172 & 4.60 & 0.00780 & 4.558 & 0.960 & 2.0478 & 0.00113 & 6 \\
\hline 2013_Sun2 & 0.218 & 3.58 & 0.00862 & 5.446 & 0.966 & 2.3545 & 0.00116 & 6 \\
\hline $\begin{array}{l}2013- \\
\text { Shade2 }\end{array}$ & 0.151 & 3.25 & 0.00602 & 4.569 & 0.964 & 1.1926 & 0.00082 & 6 \\
\hline 2009_Sun1 & 0.149 & 7.44 & 0.00906 & 7.083 & 0.996 & 0.5613 & 0.00027 & 11 \\
\hline 2009 & 0.154 & 7.45 & 0.00900 & 6.860 & 0.993 & 29.6503 & 0.00194 & 11 \\
\hline 2009_Sun2 & 0.207 & 6.10 & 0.01115 & 7.637 & 0.946 & 1.2012 & 0.00119 & 7 \\
\hline $\begin{array}{l}2009- \\
\text { Shade2 }\end{array}$ & 0.222 & 7.34 & 0.01192 & 8.983 & 0.981 & 0.9399 & 0.00106 & 7 \\
\hline
\end{tabular}

$r$ slope and $a$ intercept of regression, $R$ correlation coefficient, $E$ and $S E$ error and standard error of estimation, $n$ number of corresponding observations. Values of equation parameters are calculated for days, and accumulated degree-days (sum of effective temperatures, SET), $K$ upper asymptote of equation (maximal value of relative mine surface), and corresponding parameter in Verhulst equation assumed as $\mathrm{K}=1$ 
Table 4 Probability of differences between pairs of logistic regressions coefficients for mine area (covariance analysis model). Significant differences estimated with Bonferroni adjustment for $k=64$ and $p^{\prime}=0.000781$ (marked in bold)

\begin{tabular}{|c|c|c|c|c|c|c|c|c|}
\hline & 2013_Sun1 & 2013_Shade1 & 2013_Sun2 & 2013_Shade2 & 2009_Sun1 & 2009_Shade1 & 2009_Sun2 & 2009_Shade2 \\
\hline 2013_Sun1 & & 0.02456 & 0.13713 & 0.00354 & 0.00014 & 0.00030 & 0.00119 & 0.00244 \\
\hline $\begin{array}{l}2013 \text { Shade1 } \\
\quad\end{array}$ & 0.02456 & & 0.14488 & 0.00883 & 0.00022 & 0.00049 & 0.01149 & 0.00254 \\
\hline 2013_Sun2 & 0.13713 & 0.14488 & & 0.00257 & 0.00050 & 0.00127 & 0.07476 & 0.01305 \\
\hline $\begin{array}{l}2013 \text { Shade2 } \\
\text { Sha }\end{array}$ & 0.00354 & 0.00883 & 0.00257 & & 0.00013 & 0.00243 & 0.00243 & 0.00327 \\
\hline 2009_Sun1 & 0.00014 & 0.00022 & 0.00050 & 0.00013 & & 0.03745 & 0.00016 & 0.00098 \\
\hline $\begin{array}{l}2009 \\
\text { Shade1 }\end{array}$ & 0.00030 & 0.00049 & 0.00127 & 0.00131 & 0.03745 & & 0.00043 & 0.00275 \\
\hline 2009_Sun2 & 0.00119 & 0.01149 & 0.07476 & 0.00243 & 0.00016 & 0.00043 & & 0.00268 \\
\hline $\begin{array}{l}2009 \\
\text { Shade2 }\end{array}$ & 0.00244 & 0.00254 & 0.01305 & 0.00327 & 0.00098 & 0.00275 & 0.00268 & \\
\hline
\end{tabular}

variation of leaf microclimate and/or nutritional value of the leaf tissue. The role of microclimate variability on insect development was analysed by Rebaudo et al. (2016), who concluded '...that the model implemented with microclimatic data best predicted observed pest abundances for [their] study sites, but was less accurate than the global dataset model when performed at larger scales'. Therefore, the mismatch between organisms' size and the scale at which microclimate data are collected should be considered.

In spring, moths of $C$. ohridella lay eggs preferably on the leaves located in lower and middle parts of the canopy. Although larger leaves may offer habitat for more larvae, small leaves yielded a greater number of hatched moths per unit of leaf weight (Horváth and Benedek 2009). Multiplying mines area (Table 1) by blade biomass (per unit area) resulted in similar biomass consumed by larvae irrespective of the leaves insolation (Table 2). Similar results were obtained in glasshouse experiment on infested horse-chestnut saplings kept in 'high' and 'low' light conditions (Jagiełło et al. 2019). Much larger biomass consumed by the second generation's larvae, revealed in our study, suggests decreased nutritional quality of the leaf tissues. This age-dependent change might have included either depletion of primary metabolites or increased amounts of secondary compounds.
Frequency of radiation reflected by plant leaves (8970$9890 \mathrm{~nm}$ ) is shifted towards longer wavelengths in respect to solar radiation $(300-2000 \mathrm{~nm})$ reaching their surface (Peñuelas and Filella 1998; IRT_protocol 2015). Thus, sunexposed leaves' temperature could rapidly rise by as much as $10{ }^{\circ} \mathrm{C}$ relative to shaded leaves (Ansari and Loomis 1959; Lomas et al. 1971; SEOS 2015). Our data similarly indicated that the sun-exposed mines' temperature exceeded air temperature by $10^{\circ} \mathrm{C}$ (even $20^{\circ} \mathrm{C}$ in a single measurement) within minutes.

Leaf-dwelling larvae encounter specific mine environments that may differ from macro- and microclimatic conditions over the leaf surface, due to chilling effect of leaf transpiration and local fluctuations of insolation level within the foliage. When feeding on mesophyll, the mining larva removes the tissue responsible for absorption and reflectance of 40-90\% of radiation energy (Billings and Morris 1951; Jones and Rotenberg 2001; Slaton et al. 2001; Merzlyak et al. 2002). Remaining a semitransparent window increases the visible and infrared sun rays' penetration into the mine chamber that rises its temperature by several degrees over adjacent tissue temperature that we observed in our study. Moreover, the growth of mine chamber size along with larva development may further disturb this microenvironment equilibrium. It may involve elevated humidity and concentration
Table 5 Fresh and dry mass (mean \pm standard deviation) of leaf blade $\left(\mathrm{mg} \cdot \mathrm{mm}^{-2}\right)$ in sunexposed and shaded leaves in distinct points of vegetation period. The same letters denote homogeneity of means among fresh mass $(\mathrm{a}, \mathrm{b})$ and dry mass $(\mathrm{A}, \mathrm{B}, \mathrm{C})$ samples

\begin{tabular}{|c|c|c|c|c|c|c|}
\hline \multirow[t]{2}{*}{ Date } & \multicolumn{2}{|c|}{ Fresh mass $\left[\mathrm{mg} / \mathrm{mm}^{2}\right]$} & \multicolumn{2}{|c|}{ Dry mass $\left[\mathrm{mg} / \mathrm{mm}^{2}\right]$} & \multicolumn{2}{|c|}{ Percent of dry mass } \\
\hline & $\begin{array}{l}\text { Sun- } \\
\text { exposed }\end{array}$ & Shaded & $\begin{array}{l}\text { Sun- } \\
\text { exposed }\end{array}$ & Shaded & $\begin{array}{l}\text { Sun- } \\
\text { exposed }\end{array}$ & Shaded \\
\hline 2015-07-01 & $11.8 \pm 3.1^{\mathrm{a}}$ & $9.2 \pm 0.2^{\mathrm{b}}$ & $4.5 \pm 1.3^{\mathrm{A}}$ & $2.3 \pm 0.1^{\mathrm{B}}$ & $38 \%$ & $19 \%$ \\
\hline $2015-08-25$ & $13.2 \pm 1.1^{\mathrm{a}}$ & $9.9 \pm 1.7^{\mathrm{b}}$ & $5.1 \pm 0.7^{\mathrm{A}}$ & $3.0 \pm 0.9^{\mathrm{B}}$ & $39 \%$ & $23 \%$ \\
\hline $2015-09-23$ & $14.0 \pm 2.8^{\mathrm{a}}$ & $8.0 \pm 0.5^{\mathrm{b}}$ & $6.3 \pm 1.3^{\mathrm{C}}$ & $2.8 \pm 0.3^{\mathrm{B}}$ & $45 \%$ & $20 \%$ \\
\hline
\end{tabular}


Table 6 Intact leaf and air temperature $\left[{ }^{\circ} \mathrm{C}\right]$ in sun-exposed (sun) and shaded (shadow) places in the canopy of Aesculus hippocastanum during sunny midsummer day

\begin{tabular}{|c|c|c|c|c|c|c|c|c|c|c|c|c|c|}
\hline & & \multicolumn{4}{|l|}{ Leaf } & \multicolumn{4}{|l|}{ Air } & \multicolumn{4}{|c|}{ Leaf - air difference } \\
\hline & & $\mathrm{E}$ & $\mathrm{S}$ & $\mathrm{W}$ & $\mathrm{N}$ & $\mathrm{E}$ & $\mathrm{S}$ & $\mathrm{W}$ & $\mathrm{N}$ & $\mathrm{E}$ & $\mathrm{S}$ & $\mathrm{W}$ & $\mathrm{N}$ \\
\hline \multirow[t]{3}{*}{ Shadow } & Morning & 18.6 & 20.1 & 18.1 & 17.7 & 18.6 & 21.0 & 18.4 & 18.5 & 0.0 & -0.9 & -0.2 & -0.8 \\
\hline & Midday & & 25.0 & 25.1 & 24.5 & & 26.6 & 29.0 & 27.8 & & -1.6 & -3.9 & -3.4 \\
\hline & Evening & & 22.3 & 22.9 & 21.5 & & 24.0 & 22.9 & 22.9 & & -1.6 & 0.0 & -1.4 \\
\hline \multirow[t]{3}{*}{ Sun } & Morning & 23.1 & & & & 19.6 & & & & 3.5 & & & \\
\hline & Midday & & 32.8 & 36.7 & 32.0 & & 27.8 & 30.1 & 28.2 & & 4.9 & 6.6 & 3.9 \\
\hline & Evening & & 21.9 & 28.9 & & & 22.7 & 26.5 & & & -0.8 & 2.4 & \\
\hline \multirow[t]{3}{*}{ Sun-shadow difference } & Morning & 4.5 & & & & 1.0 & & & & 3.5 & & & \\
\hline & Midday & & 7.8 & 11.6 & 7.5 & & 1.2 & 1.1 & 0.3 & & 6.5 & 10.5 & 7.2 \\
\hline & Evening & & -0.4 & 5.9 & & & -1.3 & 3.6 & & & 0.9 & 2.4 & \\
\hline
\end{tabular}

Date of measurement: 2015-07-16-2015-07-19; morning = 06:50-07:30; midday = 10:10, 11:00, 14:10, 15:10-15:30; evening = 17:00, 18:00, 19:5020:20; E, S, W, N-position of the leaf blade within the canopy towards cardinal points of the horizon

of carbon dioxide (Pincebourde and Casas 2006a, b) and/or smaller and delayed heat loss due to reduced gas and water exchange in both intact and mined parts of infested leaves (Raimondo et al. 2005). In such conditions, metabolic rate of sun-exposed larvae, assessed on the $\mathrm{CO}_{2}$ release, may be up to five times higher than in non-exposed ones (Pincebourde and Casas 2006a, b). Thermal conditions within the mine may also be influenced by the colour change of remaining leaf tissue, caused by frass and cohabiting fungal and bacterial leaf parasites (Akimov et al. 2003).
Elevated temperatures in the mine may accelerate larval development (Pincebourde and Casas 2006b). Still, they may also increase the risk of their overheating or necessity to conform to unfavourably high temperatures within the mine. Such conditions prevail in large and oldest mines (Akimov et al. 2003) inhabited by older instars considered more resistant (Pincebourde and Casas 2015). Additionally, the mine environment also displays greater diurnal variability in microclimate than intact leaf tissue that, paradoxically, may significantly accelerate ectotherm development, as was

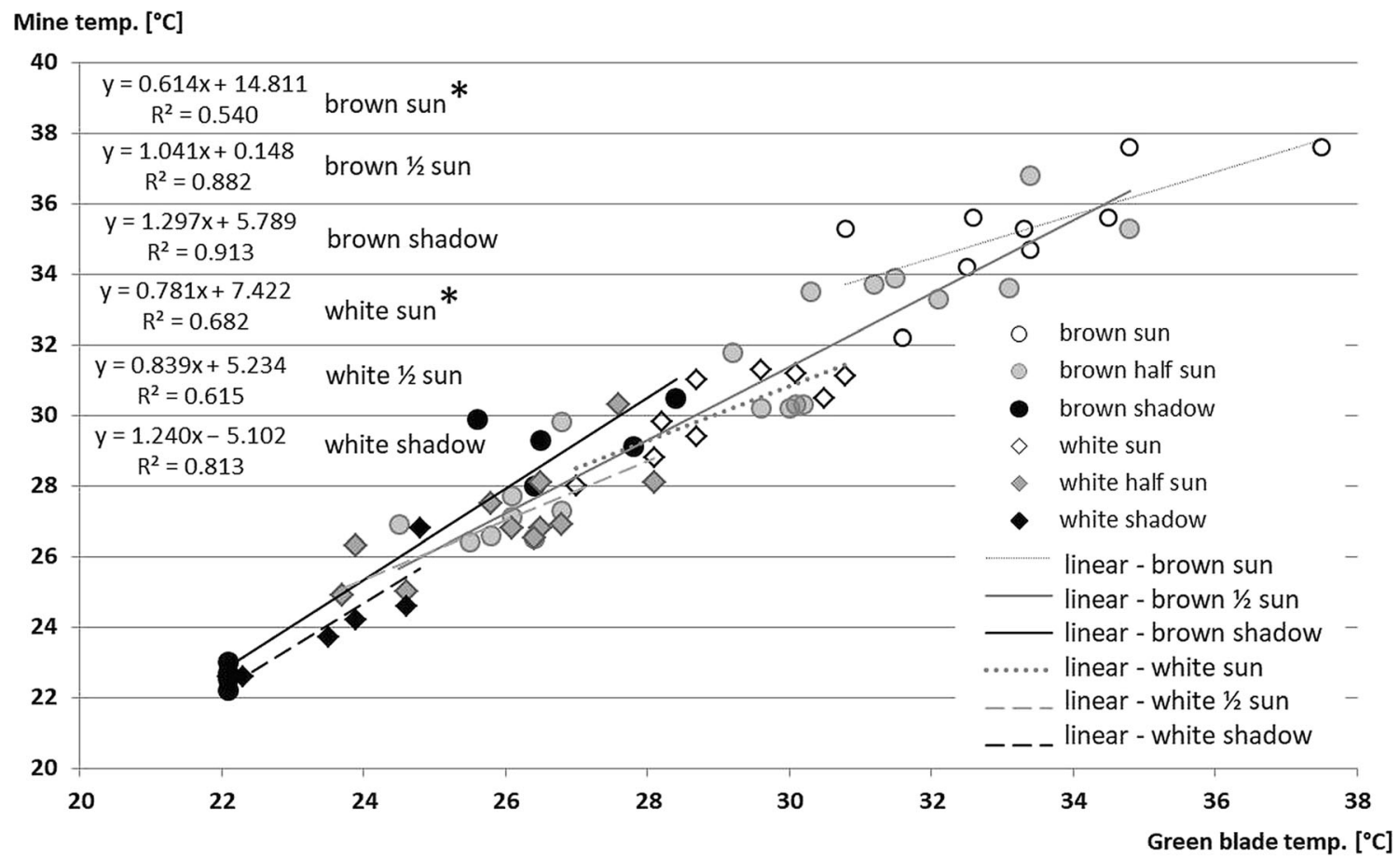

Fig. 4 Relationships between the temperature of green intact leaf blade ( $0 \mathrm{X}$ axis) and mine surface (brown, old mine; white, fresh mine) in different light conditions (sun/half-sun/shadow) (for explanation, see M\&M). (The asterisk (*) denotes significant difference between marked lines) 
demonstrated by Niehaus et al. (2012), hence further differentiate larval growth rate in the insolated and shaded mines.

Despite that, insects' vital functions under variable microclimatic conditions conform to Shelford's law of ecological tolerance, characterised by a right-skewed normal distribution (Dixon et al. 2009). As Pincebourde and Woods (2012) pointed out, 'leaf microclimate can provide suitable microhabitats in an unfavourable climate, and conversely, they can bring a species to local extinction in what would seem to be an otherwise favourable climate'.

Our results showed that either local microclimatic conditions within the mine or higher nutritive values of sun-exposed leaf tissues affected the rate of $C$. ohridella larvae development and moulting. Nevertheless, as demonstrated by our model, the time or crude sum of degree-days necessary to complete larval stage did not differ substantially between the insects inhabiting sun-exposed and shaded leaves. Thus, the model can serve as a good predictor for the timing of pest management actions.

The Verhulst logistic equation appears to be a useful model for describing numerous biological processes, especially population growth with limited resources (Tsoularis 2001; Tsoularis and Wallace 2002). Recently, Joshi et al. (2016) applied similar formulas to compare developmental time among three generations of codling moth (Cydia pomonella L.) in cultivated and abandoned apple orchards. Here, we have shown that it can be successfully applied to model development of consecutive generations of leaf-mining larvae as well.

\section{Conclusions}

Our study suggests that leaf-miner larvae can effectively compensate for microhabitat variability during their life cycle. Significant differences in microclimatic conditions and nutritional quality were 'resolved' by enhanced feeding on shaded leaves that resulted in a similar duration of larval development in both shaded and sun-exposed leaves. An elaborated mathematical model offers a convenient tool to explain whether similar compensatory reactions occur during larval development in other leaf-mining insects in variable natural conditions.

Acknowledgements Authors would like to express their gratitude to chief managers of Silesian Park in Chorzów (Silesia, Poland): Arkadiusz Godlewski, Tomasz Kaczmarek, and Dr. Aleksander Stodółka, who helped to choose and maintain the experimental stand in the Park. We also appreciate the contribution of Kinga Małek, Karolina Paździor, and Karolina Waligóra, our faculty students in collecting field data.

Availability of data and material The datasets generated during and/or analysed during the current study are available from the corresponding author on reasonable request.
Code availability ImageJ, RRID: SCR_003070 version 1.2.4

Author contribution Not applicable

Funding The research was financed by the statutory research funds of the University of Silesia in Katowice.

\section{Declarations}

Ethics approval Not applicable

Consent to participate Not applicable

Consent for publication Not applicable

Conflicts of interest The authors declare that they have no conflict of interest

Open Access This article is licensed under a Creative Commons Attribution 4.0 International License, which permits use, sharing, adaptation, distribution and reproduction in any medium or format, as long as you give appropriate credit to the original author(s) and the source, provide a link to the Creative Commons licence, and indicate if changes were made. The images or other third party material in this article are included in the article's Creative Commons licence, unless indicated otherwise in a credit line to the material. If material is not included in the article's Creative Commons licence and your intended use is not permitted by statutory regulation or exceeds the permitted use, you will need to obtain permission directly from the copyright holder. To view a copy of this licence, visit http://creativecommons.org/licenses/by/4.0/.

\section{References}

Adams SR, Langton FA (2005) Photoperiod and plant growth: a review. J Hortic Sci Biotechnol 80:2-10. https://doi.org/10.1080/14620316. 2005.11511882

Akimov IA, Zerova MD, Narolsky NB, Sviridov SV, Kohanets AM, Nikitenko GN, Gershenzon ZS (2003) Biology of a chestnut mining moth Cameraria ohridella (Lepidoptera, Gracillariidae) in Ukraine. Communication 1. Vestnik Zool 37:41-52

Alexandre NM, Humphrey PT, Gloss AD, Lee J, Frazier J, Affeldt HA III, Whiteman N (2018) Habitat preference of an herbivore shapes the habitat distribution of its host plant. Ecosphere 9:e02372. https:// doi.org/10.1002/ecs2.2372 $10 \mathrm{pp}$

Angilletta MJ Jr, Niewiarowski PH, Navas CA (2002) The evolution of thermal physiology in ectotherms. J Thermal Biol 27:249-268

Ansari AQ, Loomis WE (1959) Leaf temperatures. Am J Bot 46:713-717

Bergant K, Trdan S (2006) How reliable are thermal constants for insect development when estimated from laboratory experiments? Entomol Exp Appl 120:251-256

Billings WD, Morris R (1951) Reflection of visible and infrared radiation from leaves of different ecological groups. Am J Bot 38:327-331

Birner A, Bohlander F (2004) Mine development of horse chestnut leafminer (Cameraria ohridella) on leafs exposed to sunlight or shade. In: Kalinova B (ed) 1st International Cameraria Symposium. Cameraria ohridella and other invasive leaf-miners in Europe, Prague, Czech Republik, March 24-27, 2004. Institute of Organic Chemistry and Biochemistry ASCR, Prague, p 5

Buszko J (2006) NOBANIS - Invasive Alien Species Fact Sheet Cameraria ohridella. Online database of the North European and 
Baltic Network on Invasive Alien Species - NOBANIS. https:// www.nobanis.org. Accessed 15 March 2016

D'Costa LL, Koricheva J, Straw N, Simmonds MSJ (2013) Oviposition patterns and larval damage by the invasive horse-chestnut leaf miner Cameraria ohridella on different species of Aesculus. Ecol Entomol $38: 456-462$

Dai X-H, Xu J-S, Ding X-L (2013) Circular distribution pattern of plant modulars and endophagous herbivory within Tree crowns: the impact of roadside light conditions. J Insect Sci 13:141. https://doi.org/ 10.1673/031.013.14101

Damos P, Savopoulou-Soultani M (2012) Temperature-driven models for insect development and vital thermal requirements. Review Article. Psyche 123405:13. https://doi.org/10.1155/2012/12340

Dautbašić M (2006) Occurrence and development of Cameraria ohridella Deschka \& Dimić (Lepidoptera, Gracillariidae) in Bosnia and Herzegovina. IUFRO Working Party 7.03.10. Proceedings of the Workshop Q9 2006. Gmunden/Austria, pp 172-176. https://bfw. ac.at/400/iufro_workshop/proceedings/172-176_D4_Mirza\% 20Dautbasic_paper.pdf. Accessed 15 Mar 2015

Dimic N, Mihajlovic L, Vukca M, Peric P, Krnjajic S, Cvetkovic M (2000) Development of Cameraria ohridella Deschka \& Dimic, 1986 (Lepidoptera, Gracillariidae). Entomofauna Z Entomol 21:512

Dixon AFG, Honek A, Keil P, Kotela MAA, Sizling AL, Jarosík V (2009) Relationship between the minimum and maximum temperature thresholds for development in insects. Funct Ecol 23:257-264. https://doi.org/10.1111/j.1365-2435.2008.01489.x

Doganlar O (2008) Temperature-dependent development and degree-day model of European leaf roller, Archips rosanus. J Plant Protect Res 48:63-72

Felber R, Stoeckli S, Calanca P (2018) Generic calibration of a simple model of diurnal temperature variations for spatial analysis of accumulated degree-days. Int J Biometeorol 62:621-630

Fritz MA, Rosa S, Sicard A (2018) Mechanisms underlying the environmentally induced plasticity of leaf morphology. Front Genet 9:478. https://doi.org/10.3389/fgene.2018.00478

Gilbert M, Guichard S, Freise J, Grégoire J-C, Heitland W, Straw N, Tilbury C, Augustin S (2005) Forecasting Cameraria ohridella invasion dynamics in recently invaded countries: from validation to prediction. J Appl Ecol 42:805-813

Girardoz S, Quicke DLJ, Kenis M (2007) Factors favouring the development and maintenance of outbreaks in an invasive leaf miner Cameraria ohridella (Lepidoptera: Gracillariidae): a life table study. Agric For Entomol 9:141-158

Häffner E, Schroer S (2011) Impact of artificial illumination on the diapause induction of Cameraria ohridella (Lepidoptera: Gracilariidae). Verlust der Nacht Web. http://www.verlustdernacht. de/tl_files/VDN/_projekte/2_pdf_dokumente/Projektbeschreibung Miniermiotte-englisch.pdf. Accessed 13 Nov 2015

Hanula JL, Debarr GL, Berisford WC (1987) Threshold temperature and degree-day estimates for development of immature southern pine coneworms (Lepidoptera: Pyralidae) at constant and fluctuating temperatures. J Econ Entomol 80:62-64

Horváth B, Benedek P (2009) Development and parasitism of the horsechestnut leafminer, Cameraria ohridella, in different leaf types and canopy levels. Acta Phytopathol Entomol Hungarica 44:277-293

IRT_protocol (2015) Canopy temperature and it measurement by the infrared thermometer in selection for drought resistance. PlantStress Web. http://www.plantstress.com/methods/IRT protocol.htm. Accessed 2 Feb 2016

Jagiełło R, Baraniak E, Guzicka M, Karolewski R, Łukowski A, Giertych MJ (2019) One step closer to understanding the ecology of Cameraria ohridella (Lepidoptera: Gracillariidae): the effects of light conditions. Eur J Entomol 116:42-51
Jarosík V, Honek A, Magarey RD, Skuhrovec J (2011) Developmental database for phenology models: related insect and mite species have similar thermal requirements. J Econ Entomol 104:1870-1876

Jarošík V, Kenis M, Honěk A, Skuhrovec J, Pyšek P (2015) Invasive insects differ from noninvasive in their thermal requirements. PLoS ONE 10(6):e0131072. https://doi.org/10.1371/journal.pone. 0131072

Jones HG, Rotenberg E (2001) Energy, radiation and temperature regulation in plants. Encyclopedia of Life Sciences@ 2001, John Wiley \& Sons, Ltd. https://doi.org/10.1002/9780470015902.a0003199. pub2. Accessed 7 Oct 2015

Joshi NK, Rajotte EG, Naithani KJ, Krawczyk G, Hull LA (2016) Population dynamics and flight phenology model of codling moth differ between commercial and abandoned apple orchard ecosystems. Front Physiol 7:408. https://doi.org/10.3389/fphys.2016. 00408

Kenis M, Tomo R, Svato A, Schlinso P, Svatos A, Schlinsog P, Vaamonde CL, Heitland W, Grabenweger G, Girardoz S, Freise J, Avtzis N (2005) The horse-chestnut leaf miner in Europe - prospects and constraints for biological control. Second International Symposium on Biological Control of Arthropods, Davos, Switzerland - September 12-16:77-90. http://www.bugwood.org/ arthropod2005/vol1/2d.pdf. Accessed 24 Sept 2015

Lees DC, Lack HW, Rougerie R, Hernandez-Lopez A, Raus T, Avtzis ND, Augustin S, Lopez-Vaamonde C (2011) Tracking origins of invasive herbivores through herbaria and archival DNA: the case of the horse-chestnut leaf miner. Front Ecol Environ 9:322-328

Lomas J, Schlesinger E, Israeli A (1971) Leaf temperature measurement techniques. Bound-Layer Meteorol 1:458-465

McDonald JH (2014) Simple logistic regression. In: Handbook of Biological Statistics, 3rd edn. Sparky House Publishing, Baltimore, pp 238-246

Merzlyak MN, Chivkunova OB, Melø TB, Razi Naqvi K (2002) Does a leaf absorb radiation in the near infrared $(780-900 \mathrm{~nm})$ region? A new approach to quantifying optical reflection, absorption and transmission of leaves. Photosynth Res 72:263-270

Meshkova VL, Mikulina IM (2013) Seasonal development of horsechestnut leaf-miner, Cameraria ohridella Deschka et Dimić, 1986 (Lepidoptera: Gracillariidae) in the green stands of Kharkov. Kharkov Entomol Soc Gaz 21:29-37

Murray MS (2008) Using degree days to time treatments for insect pests. Pest Fact Sheet, Utah State University Extension and Utah Plant Pest Diagnostic Laboratory IPM-05-08 April 2008. https://climate.usurf. usu.edu/includes/pestFactSheets/degree-days08.pdf. Accessed 5 May 2015

Niehaus AC, Angilletta MJ Jr, Sears MW, Franklin CE, Wilson RS (2012) Predicting the physiological performance of ectotherms in fluctuating thermal environments. J Exp Biol 215:694-701

Nielsen AL, Chen S, Fleischer SJ (2016) Coupling developmental physiology, photoperiod, and temperature to model phenology and dynamics of an invasive Heteropteran, Halyomorpha halys. Front Physiol 7:165. https://doi.org/10.3389/fphys.2016.00165

Nietschke BS, Magarey RD, Borchert DM, Dennis D, Calvin DD, Jones E (2007) A developmental database to support insect phenology models. Crop Prot 26:1444-1448

Peñuelas J, Filella I (1998) Visible and near-infrared reflectance techniques for diagnosing plant physiological status. Trends Plant Sci 3:151-156

Pincebourde S, Casas J (2006a) Leaf miner-induced changes in leaf transmittance cause variations in insect respiration rates. J Insect Physiol 52:194-201

Pincebourde S, Casas J (2006b) Multitrophic biophysical budgets: thermal ecology of an intimate herbivore insect-plant interaction. Ecol Monogr 76:175-194 
Pincebourde S, Casas J (2015) Warming tolerance across insect ontogeny: influence of joint shifts in microclimates and thermal limits. Ecology 96:986-997

Pincebourde S, Woods HA (2012) Climate uncertainty on leaf surfaces: the biophysics of leaf microclimates and their consequences for leafdwelling organisms. Funct Ecol 26:844-853

Pocock MJO, Evans DM (2014) The success of the horse-chestnut leafminer, Cameraria ohridella, in the UK revealed with hypothesis-led citizen science. PLoS One 9. https://doi.org/10.1371/journal.pone. 0086226

Pruess KP (1983) Day-degree methods for pest management. Environ Entomol 12:613-619

Raimondo F, Trifilo P, Salleo S, Nardini A (2005) Seasonal changes of plant hydraulics, water relations and growth of Aesculus hippocastanum seedlings infested by the leaf-miner Cameraria ohridella. Ann For Sci 62:99-104

Rebaudo F, Faye E, Dangles O (2016) Microclimate data improve predictions of insect abundance models based on calibrated spatiotemporal temperatures. Front Physiol 7:139. https://doi.org/10.3389/ fphys.2016.00139

Samek T (2003) Diapause of Cameraria ohridella Deschka et Dimic and its impact on the species population dynamics. J For Sci 49(6):252258

SEOS (2015) Remote sensing and GIS in agriculture. supplement - vegetation spectral signature. Science Education through Earth Observation for High Schools (SEOS) https://www.seos-project. eu/. Accessed 7 May 2015

Slaton MR, Hunt ER Jr, Smith WK (2001) Estimating near-infrared leaf reflectance from leaf structural characteristics. Am J Bot 88:278284

Solantie R (2004) Daytime temperature sum - a new thermal variable describing growing season characteristics and explaining evapotranspiration. Boreal Environ Res 9:319-333

Stygar D, Michalczyk K, Dolezych B, Nakonieczny M, Migula P, Zaak M, Sawczyn T, Karcz-Socha I, Kukla M, Zwirska-Korczala K, Buldak R (2013) Digestive enzymes activity in subsequent generations of Cameraria ohridella larvae harvested from horse chestnut trees after treatment with imidacloprid. Pestic Biochem Physiol 105:5-12

Syeryebryennikov B, Dragan G, Shepel N, Nikitenko G, Sviridov S (2008) Ecology and control of horse chestnut leaf miner (Cameraria ohridella). $16^{\text {th }}$ International Environmental Project Olympiad - Environment-Biology, pp. 1-67. http://www.biology. org.ua/files/inepo/2008-Syeryebryennikov.pdf. Accessed 8 Nov 2014

Tomiczek C, Krehan H (1998) The horsechesnut leafmining moth (Cameraria ohridella): a new pest in Central Europe. J Arboric 24:144-148

Tsoularis A (2001) Analysis of logistic growth models. Res Lett Inform Mathl Sci 2:23-46

Tsoularis A, Wallace J (2002) Analysis of logistic growth models. Math Biosci 179:21-55

Valade R, Kenis M, Hernandez-Lopez A, Augustin S, Mena NM, Magnoux E, Rougerie R, Lakatos F, Roques A, Lopez-Vaamonde C (2009) Mitochondrial and microsatellite DNA markers reveal a Balkan origin for the highly invasive horse-chestnut leaf miner Cameraria ohridella (Lepidoptera, Gracillariidae). Mol Ecol 18: $3458-3470$

Vandermeer J (2010) How populations grow: the exponential and logistic equations. Nat Educ Knowl 3:15 https://www.nature.com/scitable/ knowledge/library/how-populations-grow-the-exponential-andlogistic-13240157/ Accessed 24 Sept 2015

Yang L, Wen K-S, Ruan X, Zhao Y-X, Wei F, Wang Q (2018) Response of plant secondary metabolites to environmental factors. Molecules 23:762. https://doi.org/10.3390/molecules 23040762

Zou L, Stout MJ, Ring DR (2004) Degree-day models for emergence and development of the rice water weevil (Coleoptera: Curculionidae) in Southwestern Louisiana. Environ Entomol 33:1541-1548

Publisher's note Springer Nature remains neutral with regard to jurisdictional claims in published maps and institutional affiliations. 